\title{
Entrepreneurial intention of university students
}

\begin{abstract}
A study was conducted to determine the perception of university students towards entrepreneurial intention. Four hundred and thirty nine students participated in the study. They comprised of university teacher preparation students from three leading research universities in Malaysia. The purpose of this study was to measure education students' entrepreneurial intention by using the Theory of Planned Behaviour. Findings indicated that there was a significant difference on entrepreneurial intention of the respondents. Those who are positive in entrepreneurial career aspiration scored higher in means intention compared to those who have no aspiration towards entrepreneurial career. This study suggests that an entrepreneurship course and proper entrepreneurial teaching strategies should be developed to create positive entrepreneurial intention and aspiration among teacher trainees. The implication of the study is to develop future teachers' entrepreneurial values so as to infuse entrepreneurship among secondary school students.
\end{abstract}

Keyword: Entrepreneurial Intention, Entrepreneurship Education, Entrepreneurial Aspiration, Teaching Strategies, University Students 